\title{
Oratorios Performed at the Holy Sepulchre in the Bohemian Lands and Austria in the 18th Century (Part II) On the Issue of Transferring Sepolcri and the Possibilities of their Semi-Staged or Staged Performance
}

Jana Perutková / perutkov@phil.muni.cz

Department of Musicology, Faculty of Arts, Masaryk University, Brno, CZ

\begin{abstract}
This part of study deals with the oratorios performed at the holy sepulchre (sepolcri) and focuses particularly on the transfer of certain compositions or librettos and on their potential stage performances. In the 18th century, among the most interesting, original phenomenons of this genre belonged the performances of particular sepolcri in various places and years, as well as the problematic of "traveling" librettos, which were arranged by various composers. Right now, the most unanswered questions concern the staged or semi-staged performance practise of these works. In any case, both the holy sepulchre and painted prospect, which was often placed in front of an altar, have noteworthy theatrical features. It seems that the staged and semi-staged performances were popular in some monastic communities; however, information about this kind of performing practise is oftentimes ambiguous. By all means, the abovementioned aspects should be a topic of further research.
\end{abstract}

\section{Keywords}

oratorio, sepolcro, Holy sepulchre, Holy Week, 18th century, Austria, Bohemian Lands, Moravia 
In the first part of this study related to oratorios performed during Holy Week by the holy sepulchre (sepolcri), we considered the genre in the wide range of forms that it acquired during the 18th century, as well as its structure and language (Musicologica Brunensia, 2018, vol. 53, Supplementum, pp. 121-153). We discussed certain aristocrats who had sepolcri composed by their composers, and especially religious orders that initiated the creation of sepolcri in many places in Austria and the Bohemian lands. Several examples have shown the types of themes that appeared in the sepolcri. This second part of the study will focus primarily on the possiblities of transferring these works, as well as on stage aspect of their performances.

\section{Transfer}

An interesting topic that deserves detailed research in the future is the transfer of specific works or librettos, especially the phenomenon of "traveling" librettos. These are librettos whose musical settings appeared in different places and in different versions, either in their original forms, in revised versions or as pasticcio, or with completely new musical settings. The identification of librettos by title is somewhat complicated by the fact that German titles often included a Latin maxim or biblical quotation. In general, two types of situations can occur with the titles. Sometimes a piece has the same or slightly different title, and it is the same or partially modified (usually shortened) version of a libretto. The sepolcro Ausgelegte schmertzliche Beweinung des angehefften Heylandes Jesu Christi, which is introduced by the text Dolorosa defletio in florenti $\mathcal{E}^{\circ}$ glorioso salutiferae crucis ligno affixi saluatoris Iesu Christi exposita, may serve as an example. ${ }^{1}$ The work was introduced by the Capuchin order in Vienna in 1704. It was performed at the same place in 1710 with the title Bis repetita threnodia pie plangens avctorem legis. Das ist: Widerholte und ausgelegte Beweinung des angehefften Heylands Jesu Christi. ${ }^{2}$ There is an undated libretto with only the title Schmertzliche Beweinung des angehefften Heylandes Jesu Christi from the Viennese Oratory order (in the A-Wn catalog dated back to 1725), which is a shortened version of the original libretto. ${ }^{3}$ Finally, a piece performed in the Viennese Augustinian order in 1730 has the same title, but it is the original, unabridged version of the text from $1704 .{ }^{4}$ Sometimes there are also situations when a completely different piece has the same or slightly different title (see below Die beschuldigte Unschuld).

One example of the re-introduction of a completely original musical work is Sant'Elena al Calvario by Antonio Caldara. Its premiere took place at the imperial court in 1731; the musical ensemble of Count Johann Adam von Questenberg introduced it in 1736 in Brno (not by the holy sepulchre, but on Palm Sunday in St. James' Parish Church), and

1 Uniquely preserved libretto in CZ-PRERa, not labeled.

2 Libretto in A-Wst, sign. A-23037.

3 A-Wn, sign. 302732-B.

4 A-Wst, sign. A-5489. 
then probably on Good Friday at the holy sepulchre in the Church of St. Margaret in Jaroměřice. ${ }^{5}$ In the same year of 1736 , this work by Caldara was presented by the Order of Knights of the Cross with the Red Star at the holy sepulchre in Prague's St. Salvator Church, thanks to a copy of the musical score promptly provided by Count von Questenberg. ${ }^{6}$ In 1737, a year after Caldara's death, it was performed again at the imperial court in Vienna, perhaps in memory of the emperor's favorite composer. ${ }^{7}$

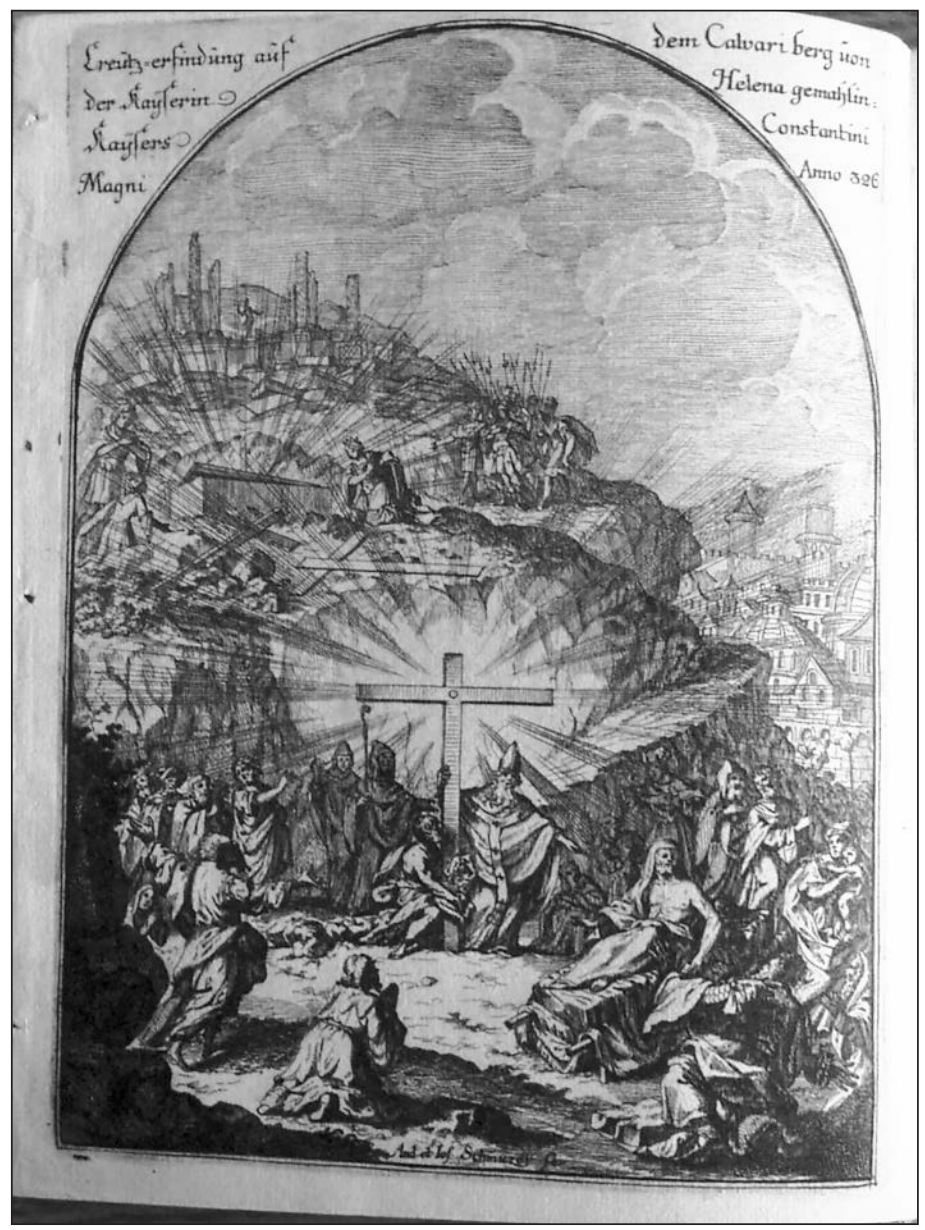

Fig. 1 Sant'Elena al Calvario, Libretto, Brno 1736, Illustration („Creütz-Erfindung auf dem Calvari berg von der Kaÿserin Helena gemahlin Kaÿsers Constantini Magni Anno 326“)

5 Libretto in CZ-R, P.I.dd.1, adl 1. The performance of the piece in Brno is undoubtedly associated with the fact that in 1736 Questenberg worked as Prinzipalkommissar (chief commissioner) at the provincial assembly held in Brno. A subsequent Jaroměřice performance can be deduced from numerous analogies, but there is no clear record.

6 FUKAČ, Jiří. Die Oratorienaufführungen bei den Prager Kreuzherren mit dem Roten Stern als Typ lokaler Musikfeste. In Sbornik praci filozofické fakulty brněnské univerzity 29, 1994, pp. 69-89, p. 81.

7 Libretto in A-Wn, sign.1814-B. 
We already discussed the complete transfer of the libretto to the sepolcro Abgesungene Betrachtungen from Vienna to Jaroměřice, and its new musical setting by František Antonín Míča (Franz Anton Mitscha). The sepolcro Die beschuldigte Unschuld is another example of a libretto transfer. It is, however, a completely different text, written decades earlier than the sepolcro of the same title Die beschuldigte Unschuld by Anton Weidner and Georg Reutter Jr., described in the first part of this study. ${ }^{8}$

The libretto Die beschuldigte Unschuld has completely different characters and storylines. The libretto written for Archbishop Esztergom, Count Emmerich Esterházy de Galántha went from Upper Hungary to Moravia, where it was significantly shortened and set by two composers, and then it went to Prague, where its new musical setting took place three decades after the original text was written. This libretto was created by Friedrich Sebastian Syhn, who acted as an occasional literary writer and clerk (Kanzelist) for Archbishop Emmerich Esterházy de Galántha in Pressburg. ${ }^{9}$ This was a single text divided into six short, separately performed oratorios, which were performed during Lent 1728, always after the Friday sermon, in the Archbishop's Pressburg residence. The music was written by Matthias Schenauer, who worked for Esterházy as a composer. The whole piece has 61 vocal numbers, so each Friday during Lent a piece with approx. 10 numbers was performed. ${ }^{10}$

Soon after its premiere, Count Johann Adam von Questenberg acquired the libretto. The text was considerably shortened (presumably by Jaroměřice dean Antonín Dubravius) and then set by his in-house composer František Antonín Míča, but its narrative was preserved. Míča's version consists of only one part containing 12 arias and two choruses, i.e. 14 vocal numbers. The role of Justice (Gerechtigkeit) was completely omitted, as well as the Choruses of the Vengeful (Chor deren Rachgierigen, or the Jews), making the text less dramatic. The Passion story is represented by the characters of the Judge, Prosecutor and the Saviour (der Richter, der Kläger, der beschuldigte Welt-Heyland), with the allegorical character of the Sympathetic Soul (Mitleydende Seele). Both choral movements - of Angels and Souls (Engeln, Seelen) - are meditative. Míčas's Die beschuldigte Unschuld was introduced on Maundy Thursday, April 14, 1729, by the Capuchin order in Olomouc ${ }^{11}$ and the following day - Good Friday - in the Church of St. Margaret in Jaroměrice. Another performance of this same work followed on Maundy Thursday in 1730 by the Capuchin order in Brno. ${ }^{12}$

8 Libretto in A-Wst, sign. A-53840. The sepolcro is not dated; it was probably created after 1738, and performed on Good Friday in the Viennese Augustinian order. The characters are: Pilate, the Prosecutor, St. John, the Daughter of Zion and the Sympathetic Soul, Chorus of Jews and Chorus of Sympathetic Souls.

9 Sebastian Syhn later worked as steward of the Austrian Gurk Abbey. Cf. BUCHINGER, Wilma - LANG, Helmut W. - MITTENDORFER, Konstanze. Burgenland, Kärnten, Niederösterreich, Oberösterreich, Salzburg [= Handbuch der historischen Buchbestände in Österreich 3], Hildesheim [u. a.]: Olms, 1996, p. 59.

10 Libretto in H-Bu, sign. H 359 [collig. 46.]: XVIII0004. I want to express my gratitude to Ladislav Kačic, who provided me information about the libretto.

11 Libretto in CZ-Bk, sign. 09 G 064.

12 Libretto in CZ-Bu, sign. CH-0007.045, No 2. 
A new musical setting of the same libretto (that is, the abbreviated version first set by Míča) stemmed from Johann Georg Orschler. ${ }^{13}$ He came from Silesian Wroclaw/Breslau and worked in various aristocratic musical ensembles: he worked for Count Johann Ludwig von Zierotin (Žerotín), who allegedly had him trained in Vienna (perhaps even by Johann Joseph Fux), as well as for Franz Anton von Rottal in Holešov/Holleschau, where he worked as Hofmeister (aulae prefectus), as Kapellmeister to Prince Johann Nepomuk Karl von Liechtenstein, and later probably as violinist to Thomas Vinciguerra von Collalto (Brtnice/Pirnitz). ${ }^{14}$ His sepolcro Die beschuldigte Unschuld was performed - like Míča's several years before - by the Capuchin order in Brno in 1733. Perhaps Orschler composed this piece for Johann Matthias von Thurn und Valsassina, the Olomouc/Olmütz canon and provost of the collegiate chapter in the St. Peter and Paul Cathedral in Brno; in any case, it survived in Valsassina's inheritance ${ }^{15}$ Finaly, the last known setting of the shortened version of Die beschuldigte Unschuld derived from Felix Benda, composer and organist at St. Michael's Church in Prague, belonging to the Servite order. The Servite order also resided in Jaroměřice, and the libretto probably came to Prague this way. Felix Benda's piece was premiered on Maundy Thursday, April 4, $1760 .{ }^{16}$

František Antonín Míča's sepolcri were typically performed in the Church of St. Margaret in Jaroměřice as well as by the Capuchin order in Brno or Olomouc. The sepolcro Die von der starcken Lieb bezwungene, von der strengen Gerechtigkeit zum Todt verurtheilte, und von der undanckbahren Welt auff das grausambste hingerichtete Unschuld, das ist: Jesus das Unschuldigste Lamb Gottes, is an analogy to this. The music was composed by the forgotten composer Johann Georg Ernst Caetan Lösel (Lesel) of Děčín, who later worked in several aristocratic musical ensembles in Germany (especially in Kleinheubach am Main). The lyrics were written by priest Franz Johann Zincke, and the piece was dedicated to Maria Philippine von Thun (the dedication takes up a whole page). It was performed at 2 o'clock in the afternoon on Good Friday in 1725, in the Chapel of St. John of Nepomuk in Podmokly (Tetschen-Bodenbach, also known as Roßawitz) at the Countess's manor in Děčín. This sepolcro was later performed in Prague by the Theatine order on at 11 am on Good Friday in 1726; this libretto understandably doesn't contain a dedication page to Countess Thun, and it doesn't mention the author of the text. ${ }^{17}$ The twopart piece contains a total of 15 vocal numbers, featuring the following allegorical characters: Guilty World, Strict Justice, Strong Love and True Innocence (die verstossene

13 Libretto in CZ-R, sign. Z.f.18, adl. 7.

14 Cf. PERUTKOVÁ, JANA. Der glorreiche Nahmen Adami. Johann Adam Graf von Questenberg (1678-1752) als Förderer der italienischen Oper in Mähren (= Specula Spectacula 4). Wien: Hollitzer Verlag, 2015, passim; ÁGÚSTSSON, Jóhannes. Joseph Johann Adam of Liechtenstein, Patron of Vivaldi. Studi vivaldiani 17, 2017, pp. 3-78. KAPSA, Václav. Böhmische Komponisten und ihre Instrumentalwerke im Schrank II. In print.

15 Cf. SPÁČILOVÁ, Jana. Unbekannte Brünner Oratorien Neapolitanischer Komponisten vor 1740. Musicologica Brunensia, 2014, vol. 49, iss. 1, pp. 137-161, p. 142.

16 Libretto in A-Wst, sign. A-94785. Felix Benda is the author of multiple sepolcri, another one being Die Schmertzen volle Mutter Gottes Maria Bey Abnehmung vom Creutz Und Begräbnuß ihres Eingebohrnen Sohns Jesu Christi from 1761. CZ-Bu, sign. ST2-0727.099.

17 Libretto from Rosawitz: CZ-Pu, sign. 34 C 19, adl. 15; libretto from the Theatines: CZ-Pu, sign. 52 B 45 , adl. 29. 
Welt, die strenge Gerechtigkeit, die starcke Liebe, die wahre Unschuld). Both librettos contain another page before the title page with the following: Musicalisches DRAMA von dem bittern Leyden und Sterben JESU CHRISTI, celebriret Annô 1725, and 1726 respectively. Emphasis on the dramatic aspect of the piece can be found on the title page, which states: In einem Musicalischen DRAMATE entworffen [...] und vorgestellet. These facts point to a probably staged or at least semi-staged performance, as the term "Dramma" was used exclusively in association with theater or theatrical scenery. This factor will be discussed in the following subchapter.

\section{Staged aspect of sepolcri}

In conclusion, we will discuss in detail the possible staged forms of oratorios meant to be performed by the holy sepulchre. ${ }^{18}$ In the 18 th century these sepolcri were performed both without dramatic action (as a purely musical production) and - according to some scholars - partially or fully staged.

The ephemeral architecture of the holy sepulchre itself, as scenery with various biblical and allegorical characters, inscriptions, distinctive candlelight, etc., represents a distinct "theatrical" element. ${ }^{19}$ Austrian researcher Albert Camesina thus described the holy sepulchre in the chronicle of the Viennese Discalced Augustinians in 1702:

"The holy sepulchre is a beautiful park with many fountains; in front of this park is a large fountain with two shells or bowls, where the water is divided into three parts and falls into the shells; on this water lies a red imperial apple with a golden cross, and in the middle where the water parts there is a monstrance. Male and female figures in five different states are kneeling on each side of this fountain, holding golden bowls from which one can drink; there are also five white lambs next to these figures, who rushed to these springs, some drinking from the lowest places. The title of this concept is literally written on the facade plate: With joy you will draw water from the wells of salvation, Isaiah 12, 3." ${ }^{20}$

18 On the functional theatrical aspect of sepolcri cf. SAMMER, Mariane. Oratorium und Fastenmeditation im funktionalen Kontext. In Musik als Spiegel der Lebenswirklichkeit im Barock. XXV. Internationale wissenschaftliche Arbeitstagung Michaelstein, 13. - 15. Juni 1997. Eds. Günter Fleischheuer, Wolfgang Ruf, Bert Siegmund and Frieder Zschoch. Michaelsteiner Konferenzberichte 57, 2001, pp. 81-92.

19 Cf. HERSCHE, Peter. Muße und Verschwendung. Europäische Gesellschaft und Kultur im Barockzeitalter, Freiburg: Herder, 2006, passim.

20 "Das H. Grab, praesentirt einen schönen Lustgartten mit lauter springbrünen, in mitten dises Gartten stunde ein grosser springbrun mit 2 muschen, oder schallen, worinnen sich dass wasser in der höche in 3 thail spaltet, vnd in die muschel fallete, ob disem wasser lage ein rother Reichs Apfel mit einem golden Creützel, in mitte unter der zerthaillung des wassers stunde dass Hoch würdige zu beeden seythen dises Brunens knüeten 5. unterschidliche standts Persohnen Mannund Weiblichen geschlechts mit goldenen schallen in Handen, welche von disem Brunen zu trinnken verlangen, neben disen Persohnen seind auch 5. weisse Lampel, welche Thails zu disen Brunen eileten vnd thails aus der untersten schallen wasser truncken, zu sehen gewest. Dises Concepts uberschrifft ware auswendig an der faccada in dem schild zu lessen: Haurietis aquas de fontibus Salvatoris Isaias." CAMESINA, Albert Ritter von. Das Passionsspiel bei St. Stephan in Wien. In Berichte und Mitteilungen Alterthums-Vereines zu Wien, Bd. 10, Heft 1, 1866, pp. 327-348. 
Similarly as in the theater, a painted backdrop was often placed in the churches, usually situated in front of the altar, while the holy sepulchre was often situated in the side chapels of the church. As is well known, some scenery designs by Giuseppe Galli Bibiena created for these purposes have been preserved. ${ }^{21}$ Matters of period performing practice relate largely to the specific form of staging during performance of oratorios by the holy sepulchre, but this has so far not been researched. Unfortunately the lack of sources will make it nearly impossible to answer this satisfactorily. Even archival research carried out by Jiř́i Sehnal in the Augustinian Canon order in Šternberk/Sternberg did not reveal anything further about practical performing matters, although it did reveal the hitherto unknown performance of sepolcri in the local Church of the Holy Trinity from 1731 to 1770 (with only a few exceptions). ${ }^{22}$ If we knew where the musicians and especially the singers were placed during the performance, we could more reliably determine what a semi-staged performance looked like, as mentioned by many musicologists, specifically Winton Dean, as well as Robert Haas, Howard Smither, Thomas Hochradner, ${ }^{23}$ and Michael Talbot. ${ }^{24}$ If the singers stood in front of the holy sepulchre or a backdrop, they could truly perform in stylized costumes and sing with the use of a few gestures that were inherently associated with Baroque theater (including musical theater). Even the relatively well-researched sources from the Moravian Jaroměřice church of Count von Questenberg have not yet provided a clear answer to this question. There is a mention of a staged performance of

21 Not only for the imperial court, but also for Servites in 1738. I would like to thank Andrea SommerMathis for this information. In the previous period, the most significant author of sepolcri scenery designs was imperial court architect and stage designer Ludovico Ottavio Burnacini.

22 On Augustinian Canons SEHNAL, Jiří. Hudba u řeholních kanovníků sv. Augustina na Moravě v 17 . a 18. století, část I. - Olomouc [Music of the Order of Canons Regular of St. Augustine in Moravia in the 17th and 18th Century, Part I - Olomouc]. Hudebni věda 52, 2015, iss. 3/4, pp. 245-272. THE SAME. Hudba u řeholních kanovníků sv. Augustina na Moravě v 17. a 18. století, část II. - Šternberk [Music of the Order of Canons Regular of St. Augustine in Moravia in the 17th and 18th Century, Part II - Sternberg]. Hudebni věda 54, 2017, iss. 4, pp. 377-440.

23 DEAN, Winton. Oratorio on the Stage. In The Musical Times, Vol. 119, No. 1630 (Dec., 1978), pp. 10301031. HAAS, Robert. Eberlins Schuldramen und Oratorien. Studien zur Musikwissenschaft, 8, 1921, pp. 9-44. SMITHER, Howard E. A history of the oratorio, Vol. 1: the oratorio in the baroque era: Italy, Vienna, Paris. Chapel Hill: University of North Carolina Press, 1977. HOCHRADNER, Thomas. Von zaghaftem Nachhall: zur Rezeptionsgeschichte der Oratorien von Johann Joseph Fux. Musicologica Brunensia, 49, 2014, iss. 1, pp. 121-135.

24 Talbot reports differences at the imperial court, especially between Leopoldine and Josephinian sepolcri. He records a certain similarity between sepolcri and the common oratorio in the sense that dramaturgy and poetic language are "arcaded", the plots are simplified, the number of characters is decreased and a two-part structure is introduced. He states that the characteristic costumes and sophisticated backdrops forming a scenic background remained. Finally, he states that thanks to these changes, the term "oratorio di sepolcro" was preferred for sepolcri ("Nella sua forma originale, il sepolcro si distingueva per il fatto di non essere diviso nelle due parti usuali, come invece avveniva negli altri oratori eseguiti in gran numero presso la corte viennese durante la Quaresima, e per essere eseguito in maniera semi-scenica. Durante il regno di Giuseppe (1705-1711), comunque, si registrò un 'riavvicinamento' all'oratorio convenzionale: la drammaturgia e la lingua poetica si 'arcadizzarono', le trame furono semplificate, fu diminuito il numero dei personaggi e fu introdotta la struttura bipartita.Tuttavia rimasero i caratteristici costumi e gli elaborati fondali scenici. É per tale cambiamento che alla definizione di sepolcro fu preferita quella di oratorio di sepolcro"). TALBOT, Michael. Legami viennesi di due opere di Vivaldi «al Santo Sepolcro». In Intorno a Silvio Stampiglia. Librettisti, compositori e interpreti nell'età premetastasiana. Prefazione di Gaetano Pitarresi. Atti del Convegno internazionale di studi. Reggio Calabria, 5-6 ottobre 2007. Reggio Calabria: Laruffa, 2010, pp. 159-172. 
an oratorio dedicated to St. John of Nepomuk, as Jaroměřice dean Antonín Dubravius borrowed costumes from the castle theater for its performance. ${ }^{25}$ While this information cannot be related to Jaroměřice sepolcri, the possibility of their at least semi-staged performance can also not thus far be reliably disproven.

Detailed operational and practical questions concerning the performance of these oratorios, even at the imperial court, have not yet been elucidated. For the imperial court, however, a note by Apostolo Zeno is suggestive; it can be found in the preface to his Poesie drammatiche: "[...] I tried to create an outline and elaborate on this dramatic poetry with the best possible artistic method, of which those who cultivated it believed that because it is not intended for a theatrical rendition but for mere singing, it is not subject to [any special] rules." 26 However, a letter dated May 22, 1734 contains essential information, where he stated that he was trying to create oratorio librettos in a way that they could be performed staged, as was popular in some orderly communities. ${ }^{27}$

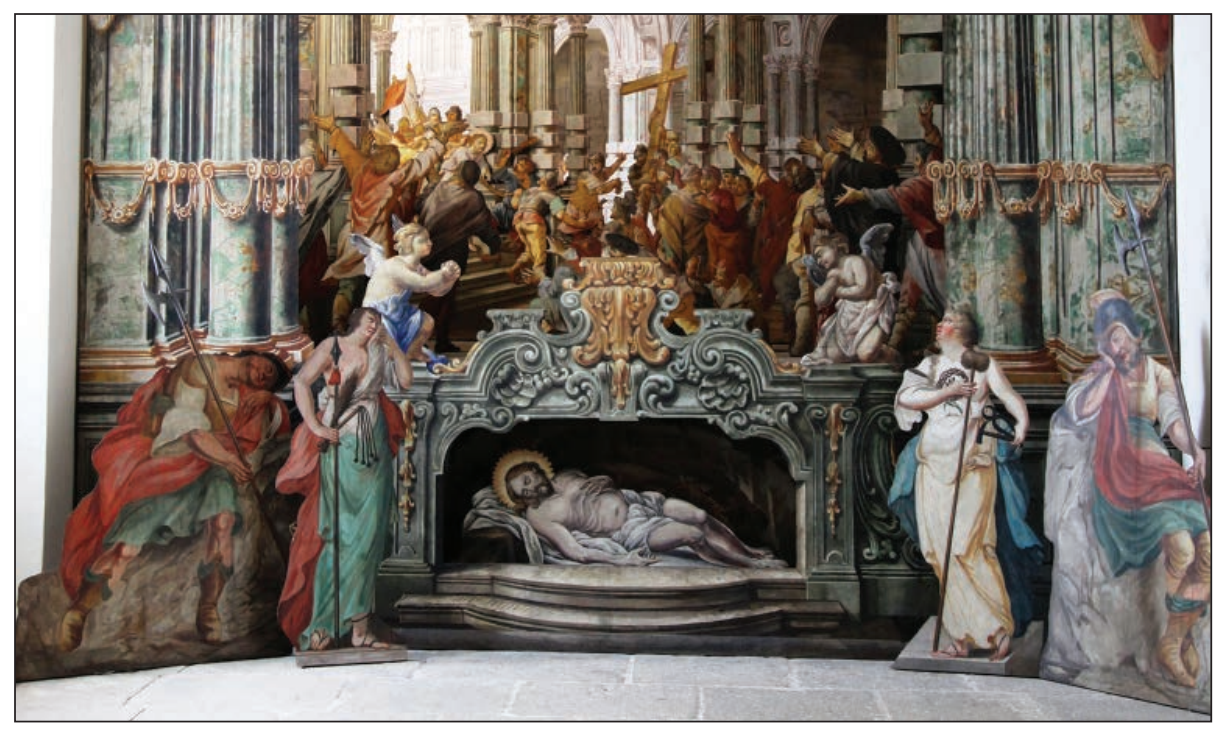

Fig. 2 Holy sepulchre, detail, Monastery Zwettel, Niederösterreich, 1744, Autor: Franz Anton Danné, newly reconstructed. Foto Andreas Gamerith.

25 “aus der comedi Guarderobbe." Letter from 31st May 1731. Moravian Provincial Archive (Moravský zemský archiv), fund G 436, cartons 765, Inv. no. 6186, f. $370^{\mathrm{v}}$.

26 "Fisso adunque con tutto lo spirito in questi due importantissimi oggetti, cercai di ridurre a miglior metodo d'arte la testitura e il lavoro di questa poesia drammatica, che per non essere alla rappresentanza, ma al solo canto ordinata, credevasi da chi la coltivatv, non esser ella a regole sottoposta [...]." ZENO, Apostolo. Poesie sacre drammatiche di Apostolo Zeno istorico e poeta cesareo, cantate nella imperial cappella di Vienna. Venezia: Cristoforo Zane, 1735 , p. VIII.

27 "Mi sono dunque determinato a lasciarli uscire col primo titolo di Poesie sacre Drammatiche ec. Sappia per altro, che io ho data a questa sorte di Componimento una forma, a mio credere, più regolare di quella che prima aveva, avendone tolti via certi abusi, che più risaltavano alla vista, e ho ridotti li miei ad un segno di poter esser anche rappresentati, come di fatto alcuno. n'è stato recitato in qualche Comunità Religiosa, e con felice successo.” ZENO, Apostolo. Lettere di Apostolo Zeno, cittadino veneziano, istorico e poeta Cesareo [...], seconda edizione [...]. Volume quinto. Venezia: Francisco Sansoni, 1735, p. 10. 
As Janet Page writes, the Viennese Ursulines were one of those religious orders in which sepolcri were staged. ${ }^{28}$ Schindler writes about staged performances of Good Friday productions at Heiligenkreuz in the 18 th century. ${ }^{29}$ A reference is also made to the libretto of the sepolcro Speculum doloris et poenitentiae. Das ist Die von der Liebe und Barmhertzigkeit Gottes auf den wahren rechten Weeg zur Seeligkeit geleitete büssende Sünderin Magdalena. The title page states that the piece was performed vocally in an exemplary action ("in einer aufferbäulichen Action gesungener $[. .$.$] vorgestellet [...]"). It was performed$ on Good Friday in 1735 in Heiligenkreuz; the music was composed by Franz Pruneder. ${ }^{30}$ In the case of sepolcri by Gregor Joseph Werner, Kapellmeister of Prince Paul Anton Esterházy, we can assume their staged performance according to the formulation of the type "performed at a musical funeral scene and sung by the holy sepulchre" ("Vorgestellet in einer Musicalischen Trauer=Scen, und abgesungen Bey Dem Heiligen Grab") or "depicted in an oratorio performance" ("In einer Oratorischen Vorstellung entworffen"). Johann Harich, and recently also Austrian theater scholar Matthias J. Pernerstorfer, have researched the possibilities of staged performance of Werner's sepolcri. ${ }^{31}$

So far, research has shown that the librettos themselves, or the small number of preserved musical scores, provide much interesting information in this area of performance. It seems that the popularity of semi-staged and staged productions of sepolcri in Prague probably dates from the second half of the 18th century. We can generally say that some type of staged performance may be supposed in works termed Sing-Spiel, but the preserved librettos do not provide unambiguous evidence. ${ }^{32}$ The oratorio Deodatus à Gozzone may serve as an example. ${ }^{33}$ It was composed by Franz Habermann, an undervalued composer of outstanding qualities originally from Bohemia, who also worked as maitre de musique to Louise-Henri de Condé in Paris; his work in Prague dates back to ca. $1740 .{ }^{34}$ The libretto to his sepolcro Deodatus à Gozzone aus dem hochbefreyten ritterlichen

28 PAGE, Janet K. Convent Music and Politics in Eighteenth-century Vienna, Cambridge: Cambridge University Press, 2014. In addition to the already mentioned studies, see also PAGE, Janet K. Vienna's Ursuline Convent and the Via Allemagna: Travel, Music, Letters. Musicologica Brunensia, 2018, vol. 53, Supplementum, pp. 47-56.

29 SCHINDLER 1967/69, pp. 184-185.

30 Ibid., p. 187.

31 Cf. PERnERSTORFER, Matthias J. „Das geliebte Myrhen=Büschlein“. Von Paul I. Esterházy und dem Eisenstädter Kalvarienberg zu den Karfreitagsoratorien des Gregor Joseph Werner. In print.

32 Musical-dramatic pieces of this kind also appeared in Brno, e.g. "Ein geistliches Sing-Spiel am Karfreytage" from Joseph Prosper Seyfferdt with a title Iskariot oder Verstockung die Folge des Geizes, cf. DOKOUPIL, Vladimír. Soupis brněnských tiski̊ - staré tisky do roku 1800. Brno: Státní vědecká knihovna, 1974, p. 372.

33 Libretto in CZ-Pu, sign. 52 C 20, adl. 35. The complete title page states the following: Deodatus à Gozzone aus dem hochbefreyten ritterlichen Orden s. Joannis Hierosolymitani ein glücklicher, und siegreicher Uberwinder des abscheulichen, und gifftigen Rhodischen Drachen[.] Ein Sinnbild Christi unsers Erlösers, (welcher am Stammen des H. Creutzes den gifftigen höllischen Drachen helderzmüthig bestritten, und glorreich besieget) Vermög jenen Worten des Psalmisten: Du wirst über Nattern, und Basilischken wandeln, und wirst Löwen und Drachen zertretten Entworffen, dem glorreich afferstandenen Erlöser, als ein Siegs-Zeichen aufgeführt in der Hoch-befreyten priorats Kirchen, des hoch-gedachten ritterlichen Ordens St. Johann. Hierosol. bey unser Lieben Frauen unter der Retten in der kleineren Residentz-Stadt Prag am Fuss der Brucken bey dein Grab des Heylands vor dessen glorreicher Auferstehung am Char-Samstag im Jahr Christi MDCCLIV. nach Mittags umb 4. Uhr in einem Sing-Spiel fürgestellet.

34 ŠTĚDROŇ, Bohumír. Habermann, František Václav. In Československý hudebni slovnik osob a instituci, Vol. 1, Praha: Státní hudební vydavatelství, 1963, pp. 387-388. 
Orden s. Joannis Hierosolymitani ein glücklicher, und siegreicher Uberwinder [sic!] des abscheulichen, und gifftigen Rhodischen Drachen, performed on Holy Saturday 1754 by the Order of St. John in Prague's Church of Our Lady Under the Chain, states that the piece was performed as a Sing-Spiel ("in einem Sing-Spiel fürgestellet"), and it is labeled as a live image ("Sinnbild"). A semi-staged performance is therefore possible at the very least. The well-known and popular story of the courageous knight Gozon, of the Order of St. John, who lured a dragon out of its cave on Rhodes in 1345 and killed it with a sword, was used as a parable of Christ's victory.

In other librettos, the phrase "performed as a sung poem" (Sing-Gedicht) appears. This is also the case in Fons Aquae salientis in vitam aeternam, Das ist: Der Brunn des lebendigen Wassers In dem Begeißleten Heyland, performed in the Ursuline institute in Prague in 1753, which speaks directly about a dramatic rendition: "Durch ein Sing-Gedicht bey dem heiligen Grab deren WW.EE. Jungfrauen der Geselschafft St. Ursulae auf dem Hradschin Am Heil. Char-Freytag vorgestellet." The introduction addresses in detail where the plot takes place. ${ }^{35}$

Another libretto of a sepolcro, performed in 1752 by the Prague Ursuline institute in the St. Anne chapel of the Church of St. John of Nepomuk on Hradčany, states that the piece takes place at a mourning scene. This is a work by anonymous authors, Der In dem Göttlichen Rath von Ewigkeit beschlossene Feld-Zug der Liebe Zu Bestürm- und Eroberung der Höllen-Porten. ${ }^{36}$ Performed on Good Friday at 2 o'clock in the afternoon, the piece is labeled as a sung poem (Sing-Gedicht) that was performed at an ephemeral mourning architecture ("Bey einem dieses Geheimnuß vorstellenden Trauer-Gerüst entworffen"). The title page is followed by an "Entwurf", which represents a kind of introduction to a situation (similar to the Argomento in opera); in its conclusion, it states that the piece is intended "to be a stimulating example worthy of following at our mourning scene". ${ }^{37}$ The allegorical characters that appear in the sepolcro are the Almighty Mercy of the Father (die allmögende Barmherzigkeit des Vaters), the Endless Love of the Son (die unermessene Liebe des Sohns), the Soul Shrouded by Everlasting Extinction (die den ewigen Untergang drohende Gefangenschaft der Seelen) and the So Wonderfully Achieved Liberation (die so wunderbar geschehene Befreyung). It is a two-part work, with the first part consisting of 4 sections and the second of 7 sections, for a total of 11 sung numbers. The beginning of the second part presents a text that is not a quotation of the Bible.

35 Libretto in CZ-Pu, sign. H 788. The beginning of the introductory text ("Vorbericht") states: "Es stellet dieses Sing-Gedichte einen der schmerzhaffftigsten Theilen des Leydens unseres Erlösers vor [...]”. The end of the text states: The whole story takes place in the foyer of Pilate's courtroom, which is dramatically presented by paintings on the holy sepulchre, as well as poetic art citing different parts of the Bible and the word of the Holy Fathers. ("Die ganze Handlung ist auf dem Vorhof des Richt-Saals Pilati, welches sowohl die Mahl-Kunst in dem Heil, Grab, als die Dicht-Erfindung Dramatisch mit fast gänzlicher Entlehnung verschiedener Stellen der Heil. Schrifft, und deren Meynungen der heiligen Vättern vorstellet.")

36 Der In dem Göttlichen Rath von Ewigkeit beschlossene Feld-Zug der Liebe Zu Bestürm- und Eroberung der Höllen-Porten. Das Geheimnuß Der Schmertzhaften Creutz-Tragung Unsers Heylands Mit einem Geistlichen Sing-Gedichte In der Kirchen deren Wohl-Ehrwürdigen Geistlichen Jungfrauen der Gesellschaft der H. Ursulä ob dem Hradschin bey St. Anna genannt, Bey einem dieses Geheimnuß vorstellenden Trauer-Gerüst entworffen Am Heil. Char-Freytag um 2. Uhr Nachmittag. Alt-Stadt Prag: gedruckt im Königs-Hof bey Frantz Carl Hladky, Hochfürstl. Ertz-Bischöffl. Buchdrucker, [1752]. Libretto in CZ-Pu, sign. G 1648.

37 "an unser Trauer-Bühne ein ermunterndes Beispiel der Nachfolge anzuwerben [...]." 
It is rather a description of the scene which presents a choice of scenical proposal in which God Decision says, like the word of the Father was said before, that according to hereditary guilt, he will redeem the world with a disgraceful death on the cross. ${ }^{38}$ The second part of the piece is introduced by a text: "[...] it presents [a scene] for a field expedition to Golgotha of immense divine love, with which human eligibility for heaven has opposed the prison of hell, but has decided to exclude the fallen angels from its fruit." 39

The terms Sing-Gedicht and dramatic performance ("drammatisch vorgestellet") also appear in the oratorio performed by the holy sepulchre in Prague's Loreto church in 1760. The title page states: Gedeon: ein geistliches Sing-Gedichte, das zu einem Schwerd gewordene Brod Gedeonis, als ein Vorbild ds Allerheiligsten Altar-Geheimüsses [...] drammatisch vorgestellet, und geistlich betrachtet. The music and lyrics were written by Prague composer Anton Moritz Taubner. ${ }^{40}$ It does not state on which day of Holy Week it was performed, but it does say that it began at 5 o'clock in the afternoon. The piece bears the name of the famous Old Testament judge Gideon, who fought against Midian invaders. Taubner was not the first to bring this Old Testament theme into a sepolcro. In 1737 the oratorio Il Gedeone was composed by Nicola Porpora, and performed on Good Friday 1740 by the Order of Knights of the Cross with the Red Star in Prague. ${ }^{41}$ However, the main characters and plot are different in Taubner's piece. Shulamit appears as a parable of the Christian Soul in the image of Gideon. The character of Shulamit created a connections for verbal and moral comprehension. ${ }^{42}$ The other characters are Gideon, leader of the Israelites, armiger Phara, and the two Midian soldiers Apomassar and Thessalon. The choruses represent two quarreling nations, the Midians and the Israelites.

The piece contains 12 vocal numbers, but its form is very atypical. According to ancient teachings of rhetoric, the introduction is called the Syncrisis, and is quite an extensive text. This is followed by a certain prologue (Vorspiel), which presents a Lamento (long recitative and aria), "failing Shulamit" (die verzagte Sulamit). This prologue is followed by another text introducing listeners to the story (Inhalt des Sing-Gedichtes), which is followed in turn by the beginning of the first part. This is introduced by a text that clearly alludes to a staged performance, i.e. a description of a scene (ascent-Auftritt): on one side, the scene includes a backdrop of Mount Ephraim, ${ }^{43}$ with the Gilead mountains

38 "Stellet vor die Wahl des Entwurfs in dem Göttlichen Rath Schluss, kraft welcher sich das Wort des Vatters zuvor verordnet hat, nach vorgesehener Erb-Schuld die Welt mit den Schmach-vollen Tod des Creutzes zu erkauffen."

39 "Stellet vor den Feld-zug nach der Schedlstatt unermessener Göttlicher Liebe, durch welchen Sie die Menschliche Himmels-Fähigkeit wider die Gefangen-Haltung der Höllen erforchten, die gefallene Engeln aber von denen Früchten derenselben außzuschliessen sich entschlossen hat."

40 In the printed libretto housed in CZ-Pu, sign.52 C 20, adl. 33, is mentioned: Die Dicht- und Thon-Kunst dieses Wercks ist eine Erfindung des Herrn Ant. Morice Taubner. On Taubner cf. MARŠÍKOVÁ MICHÁLKOVÁ, Alena. Anonymni oratorium Das siebenfältig Verunreinigte (1746) z loretánské hudebni sbirky [Anonymous Oratorio „Das siebenfältig Verunreinigte“ (1746) from the Loreta Musical Collection]. Bachelor's thesis, Prague: Charles University, 2014.

41 Libretto in CZ-Pu, sign. 52 C 08, adl. 5.

42 "Sulamitis: Die christliche Seele ein Bild des Gedeons, machet in den Vor- und Zwischen-Spielen den Zusammenhang des Wort- und sittlichen Verstandes."

43 Northern Galilean upland and southern mountains - i.e. Ephraim (Samara) and Judean Mountains. 
on which Gideon broke camp in the foreground; on the other side lies a section of the Israeli valley that shows the Midian night fires, including several tents along the banks of Jordan. The story begins in late twilight and lasts until midnight. ${ }^{44}$ This is followed by a biblical quotation ("Grundsatz"), and then the actual text of the piece starts. The first part contains only two arias, and is followed by the first interlude, in which Shulamit is summoning her courage. The second part offers another description: the scene depicts a huge camp of Midians, Amalekites and all allies from the East, of whom some sleep and others guard patrols by their fires at midnight..$^{45}$ The second part also contains only two arias. In the second interlude, the monologue is led by the now bold Shulamit (Die getröste Sulamit, again a recitative and aria). Then comes the third part. ${ }^{46}$ It is accompanied by continuous music, with alternating recitatives - probably accompanied by an orchestra - and choruses; the conclusion of this part is a duet with Gideon and Phara. The last interlude of the triumphant Shulamit follows, and then the final chorus, entitled Gideon's Gratitude (Der Danckbarkeit Gedeonis). It ends with these words: "Gott der hat heunt durch ein Brod Israël befreit von Tod welchs täglich von Himmel fallt." The author therefore didn't even try to create a parable of Jesus' death and resurrection. It is indisputable that this work, in its structure, description of scenes, and even its story, evokes opera, and it departs from the contemplative compositions reminiscent of Christ's sufferings that were characteristic of this genre. However, not even this piece can be clearly considered a theatrical rendition, because the battles that the libretto describes were inappropriate for staged rendering in a church. It is therefore not yet possible to give a clear answer concerning the semi-staged or staged performance of sepolcri in various locations based on the source samples studied so far.

The present study is a general introduction to oratorios performed by the holy sepulchre during Holy Week. It is an overview that points to the wide range of forms of these pieces, as well as to individual questions that need to be examined in more detail in the future. Specific examples from different areas were demonstrated to point to the multiplicity of this issue. ${ }^{47}$ Many questions will be answered only by more detailed research.

44 "Erster Auftritt: Die Scen stellet auf einer Seiten in Prospect das Ephraimische Gebürge, in Gesicht aber den Berg Galaad vor, auf welchen Gedeon ein Laager gestochen; zur anderen Seiten zieget sich ein Theil des Thals Jezrael, in welchen einige Nacht-Feuer deren Madianittischen Vor-Wachten, sannt einigen Zelten längst den Gesatte des Jordans zu sehen. Die Handlung hat ihren Anfang bey später Demmerung, und dauret bis Mitternacht."

45 "Anderter Auftritt. Die Scen stellet das ungeheuere Laager deren Madianitter, Amalecitten, famt aller festlichen Bundes Genossenen vor, davon in Gesichte einige Theils schlaffende, theils wachende Vorposten bey ihren Feuern zu sehen, die Handlung ist in Mitternacht."

46 Part Three offers the following description: the scene presents the area surrounding Bethabara and Bethsetta on the river Jordan, where the two contending sides broke their camps, and takes place several hours before sunrise. ("Dritter Auftritt. Die Scen entwerfet die Gegend um Bethbera, und Bethsetta an den Jordan, in welcher beede streittende Partheyen ihr Laager geschlagen, die Handlung ist einige Stunden vor Aufgang der Sonnen.”)

47 I would like to thank Otto Biba, Ondřej Macek, Vladimír Maňas, Vlasta and Hubert Reitterer, Jiří Sehnal, Petr Slouka and Jana Spáčilová for their consultation on this topic. 


\section{Bibliography}

\section{Sources}

Ausgelegte schmertzliche Beweinung des angehefften Heylandes Jesu Christi. [Anon.], CZ-PRERa, not labeled.

Bis repetita threnodia pie plangens avctorem legis. Das ist: Widerholte und ausgelegte Beweinung des angehefften Heylands Jesu Christi. [Anon.], A-Wst, sign. A-23037.

Deodatus à Gozzone. ([?]/Franz Habermann), CZ-Pu, sign. 52 C 20, adl. 35.

Die beschuldigte Unschuld. (Andreas Weidner/Georg Reutter jr.) A-Wst, sign. A-53840.

Die beschuldigte Unschuld. (Friedrich Sebastian Syhn/Matthias Schenauer), H-Bu, sign. H 359 [collig. 46.]: XVIII0004.

Die beschuldigte Unschuld. (Friedrich Sebastian Syhn/František Antonín Míča), CZ-Bk, sign. 09 G 064.

Die beschuldigte Unschuld. (Friedrich Sebastian Syhn/František Antonín Míča), CZ-Bu, sign. CH0007.045, adl. 2.

Die beschuldigte Unschuld. (Friedrich Sebastian Syhn/Johann Georg Orschler), CZ-R, sign. Z.f.18, adl. 7.

Die beschuldigte Unschuld. (Friedrich Sebastian Syhn/Felix Benda), A-Wst, sign. A-94785.

Die Schmertzen volle Mutter Gottes Maria Bey Abnehmung vom Creutz Und Begräbnuß ihres Eingebohrnen Sohns Jesu Christi. ([?]/Felix Benda), CZ Bu, sign. ST2-0727.099.

Die von der starcken Lieb bezwungene, von der strengen Gerechtigkeit zum Todt verurtheilte, und von der undanckbahren Welt auff das grausambste hingerichtete Unschuld, das ist: Jesus das Unschuldigste Lamb Gottes. (Franz Johann Zincke/Georg Ernst Caetan Lösel), CZ-Pu, 34 C 19.

Die von der starcken Lieb bezwungene, von der strengen Gerechtigkeit zum Todt verurtheilte, und von der undanckbahren Welt auff das grausambste hingerichtete Unschuld, das ist: Jesus das Unschuldigste Lamb Gottes. (Franz Johann Zincke/Georg Ernst Caetan Lösel), CZ-Pu, sign 52 B 45.

Der In dem Göttlichen Rath von Ewigkeit beschlossene Feld-Zug der Liebe Zu Bestürm- und Eroberung der Höllen-Porten. [Anon.], CZ-Pu, sign. G 648.

Fons Aquae salientis in vitam aeternam. [Anon.], CZ-Pu, sign. H 788.

Gedeon. (Anton Moritz Taubner/Anton Moritz Taubner), CZ-Pu, sign. 52 C 20, adl. 33.

Il Gedeone. ([?]/Nicola Porpora), CZ-Pu, sign. 9 F 3726.

Sant' Elena al Calvario. (Pietro Metastasio/Antonio Caldara), CZ-R, P.I.dd.1, adl. 1.

Sant' Elena al Calvario. (Pietro Metastasio/Antonio Caldara), A-Wn, sign.1814-B.

Schmertzliche Beweinung des angehefften Heylandes Jesu Christi. [Anon.], A-Wn, sign. 302732-B.

Schmertzliche Beweinung des angehefften Heylandes Jesu Christi. [Anon.], A-Wst, sign. A-5489.

MZA, fund G 436, cartons 765, Inv. no. 6186.

\section{Literature}

ANONYMUS. Sehenswürdigkeiten und Kunstschätze des Stiftes Zwettl. Österreichs Museen stellen sich vor 16, 1982, Wien: Bundesministerium für Wissenschaft und Forschung, pp. 16-23.

ÁGÚSTSSON, Jóhannes. Joseph Johann Adam of Liechtenstein, Patron of Vivaldi. Studi vivaldiani 17, 2017, pp. 3-78. 
BUCHINGER, Wilma - LANG, Helmut W. - MITTENDORFER, Konstanze. Burgenland, Kärnten, Niederosterreich, Oberosterreich, Salzburg [= Handbuch der historischen Buchbestände in Osterreich 3], Hildesheim [u. a.]: Olms, 1996, p. 59.

CAMESINA, Albert Ritter von. Das Passionsspiel bei St. Stephan in Wien. Berichte und Mitteilungen Alterthums-Vereines zu Wien, Bd. 10, Heft 1, 1866, pp. 327-348.

DEAN, Winton. Oratorio on the Stage. The Musical Times, Vol. 119, No. 1630 (Dec., 1978), pp. $1030-1031$.

DOKOUPIL, Vladimír. Soupis brněnských tisků - staré tisky do roku 1800. Brno: Státní vědecká knihovna, 1974.

GAMERITH, Andreas. Neufunde zum Heiligen Grab in Stift Zwettl: Eine Weihnachtsbespielung aus den 1760ern. Paper presented at the workshop Vom Aschermittwoch bis zum Heiligen Grab. Passion und Theater im Barock: held on April 21-22, 2015, Don Juan Archiv, in Wien.

FUKAČ, Jiří. Die Oratorienaufführungen bei den Prager Kreuzherren mit dem Roten Stern als Typ lokaler Musikfeste. Sbornik prací filozofické fakulty Brněnské univerzity 29, 1994, pp. 69-89, p. 81.

HAAS, Robert. Eberlins Schuldramen und Oratorien. Studien zur Musikwissenschaft 8, 1921, pp. 9-44.

HARICH, Johann. Szenische Darstellungen und Oratorien-Aufführungen im 18. Jahrhundert am Esterházy-Hof zu Eisenstadt. Burgenländische Heimatblätter 38, 1976, pp. 112-130.

HERSCHE, Peter. Muße und Verschwendung. Europäische Gesellschaft und Kultur im Barockzeitalter, Freiburg: Herder, 2006.

HOCHRADNER, Thomas. Von zaghaftem Nachhall. Zur Rezeptionsgeschichte der Oratorien von Johann Joseph Fux. Musicologica Brunensia 49, 2014, iss. 1, pp. 121-135.

KAPSA, Václav. Böhmische Komponisten und ihre Instrumentalwerke im Schrank II. In print.

MARŠÍKOVÁ MICHÁLKOVÁ, Alena. Anonymni oratorium Das siebenfältig Verunreinigte (1746) z loretánské hudebni sbirky [Anonymous Oratorio „Das siebenfältig Verunreinigte“ (1746) from the Loreta Musical Collection]. Bachelor's thesis, Praha: Karlova univerzita, 2014.

PERNERSTORFER, Matthias J. „Das geliebte Myrhen=Büschlein“. Von Paul I. Esterházy und dem Eisenstädter Kalvarienberg zu den Karfreitagsoratorien des Gregor Joseph Werner. In print.

PAGE, Janet K. Convent Music and Politics in Eighteenth-century Vienna, Cambridge: Cambridge University Press, 2014.

PAGE, Janet K. Vienna's Ursuline Convent and and the Via Allemagna: Travel, Music, Letters. Musicologica Brunensia, 2018, vol. 53, Supplementum, pp. 47-56.

PERUTKOVÁ, Jana. Der glorreiche Nahmen Adami. Johann Adam Graf von Questenberg (1678-1752) als Förderer der italienischen Oper in Mähren (Specula Spectacula 4). Wien: Hollitzer Verlag, 2015.

SAMMER, Mariane. Oratorium und Fastenmeditation im funktionalen Kontext. In Musik als Spiegel der Lebenswirklichkeit im Barock. XXV. Internationale wissenschaftliche Arbeitstagung Michaelstein, 13.-15. Juni 1997. Eds. Günter Fleischheuer, Wolfgang Ruf, Bert Siegmund and Frieder Zschoch. Michaelsteiner Konferenzberichte 57, 2001, pp. 81-92.

SEHNAL, Jiří. Hudba u řeholních kanovníků sv. Augustina na Moravě v 17. a 18. století, část I. Olomouc. [Music of the Order of Canons Regular of St. Augustine in Moravia in the 17th and 18th Century, Part I - Olomouc]. Hudebni věda 52, 2015, iss 3/4, pp. 245-272.

SEHNAL, Jiří. Hudba u řeholních kanovníků sv. Augustina na Moravě v 17. a 18. století, část II. Šternberk [Music of the Order of Canons Regular of St. Augustine in Moravia in the 17th and 18th Century, Part II - Sternberg]. Hudebni věda 54, 2017, iss. 4, pp. 377-440.

SCHINDLER, Otto G. Über spätbarockes Christi-Leiden-Spiel im Viertel unter dem Wienerwald. Unsere Heimat: Monatsblatt des Vereins für Landeskunde von Niederösterreich und Wien 38, 1967, pp. 225-227. 
SCHINDLER, Otto G. Die Libretto-Sammlung des Stiftes Klosterneuburg. Jahrbuch des Vereines für Geschichte der Stadt Wien, 23/25, 1967/1969, pp. 183-197.

SMITHER, Howard E. A history of the oratorio, Vol. 1: the oratorio in the baroque era: Italy, Vienna, Paris. Chapel Hill: University of North Carolina Press, 1977.

SPÁČILOVÁ, Jana. Unbekannte Brünner Oratorien Neapolitanischer Komponisten vor 1740. Musicologica Brunensia 49, 2014, iss. 1, pp. 137-161.

ŠTĚDROŇ, Bohumír. Habermann, František Václav. In Československý hudebni slovnik osob a institucí, Vol. 1. Praha: Státní hudební vydavatelství, 1963, pp. 387-388.

TALBOT, Michael. Legami viennesi di due opere di Vivaldi «al Santo Sepolcro». In Intorno a Silvio Stampiglia. Librettisti, compositori e interpreti nell'età premetastasiana. Prefazione di Gaetano Pitarresi. Atti del Convegno internazionale di studi. Reggio Calabria, 5-6 ottobre 2007. Reggio Calabria: Laruffa, 2010, pp. 159-172.

ZENO, Apostolo. Poesie sacre drammatiche di Apostolo Zeno istorico e poeta cesareo, cantate nella imperial cappella di Vienna. Venezia: Cristoforo Zane, 1735.

ZENO, Apostolo. Lettere di Apostolo Zeno, cittadino veneziano, istorico e poeta Cesareo [...], seconda edizione [...]. Volume quinto. Venezia: Francisco Sansoni, 1735. 
